\title{
Arctic Ocean Scientific Drilling: The Next Frontier
}

\author{
by Bernard Coakley and Ruediger Stein
}

\section{Introduction}

The modern Arctic Ocean appears to be changing faster than any other region on Earth. To understand the potential extent of high latitude climate change, it is necessary to sample the history stored in the sediments filling the basins and covering the ridges of the Arctic Ocean. These sediments have been imaged with seismic reflection data, but except for the superficial record, which has been piston cored, they have been sampled only on the Lomonosov Ridge in 2004 during the Arctic Coring Expedition (ACEX-IODP Leg 302; Backman et al., 2006) and in 1993 in the ice-free waters in the Fram Strait/Yermak Plateau area (ODP Leg 151; Thiede et al., 1996).

Although major progress in Arctic Ocean research has been made during the last few decades, the short- and long-term paleoceanographic and paleoclimatic history as well as its plate-tectonic evolution are poorly known compared to the other oceans. Despite the importance of the Arctic in the climate system, the database we have from this area is still very weak. Large segments of geologic time have not been sampled in sedimentary sections. The question of regional variations cannot be addressed.

Prior to 2004, the geological sampling in the Arctic Ocean was restricted to obtaining near-surface sediments, i.e., only the upper about 5-15 m could be sampled by means of gravity and piston coring. Thus, more or less, all studies were restricted to the Quaternary, with one exception (Fig. 1; e.g., Clark et al., 1980, 1986; Thiede et al., 1990). In four short sediment cores from Alpha Ridge, upper Cretaceous and lower Tertiary sediments were sampled by gravity coring from ice island T-3. Until recently (Stein, 2008), the absence of technological and logistic solutions for reaching and operating in a permanently ice-covered region thwarted further study of the Arctic Ocean; thus, we have been unable to retrieve long and undisturbed sediment cores.

With the successful completion of IODP Expedition 302 ("Arctic Coring Expedition", ACEX) - the first Mission Specific Platform (MSP) expedition within the Integrated Ocean Drilling Program (IODP) - a new era in Arctic research has begun. For the first time, scientific drilling in the permanently ice-covered Arctic Ocean was carried out, penetrating about $430 \mathrm{~m}$ of Quaternary, Neogene, Paleogene, and Campanian sediments on the crest of Lomonosov Ridge close to the North Pole (Backman et al., 2006, 2008; Moran et al., 2006).

ACEX was an outstanding success for two reasons. First, ACEX has proven that with an intensive ice-management strategy (i.e., a three-ship approach with two icebreakers Sovetskiy Soyuz and Oden protecting the drillship Vidar Viking by breaking upstream ice floes into small pieces), successful scientific drilling in the permanently ice-covered central Arctic Ocean is possible. Second, the first scientific results brought new and unexpected insights into the Arctic Ocean climate history and its global significance (Backman and Moran, 2008, and further references therein).

Despite the success of IODP Expedition 302, major questions related to the climate history of the Arctic Ocean and its long- and short-term variability during Mesozoic-Cenozoic times cannot be answered from the ACEX record due to the poor core recovery and, especially, a major mid-Cenozoic hiatus. This hiatus spans the critical time of the transition from the early Cenozoic Greenhouse world to the late Cenozoic Icehouse world (Miller et al., 1987, 1991; Lear et al., 2000; Pearson and Palmer, 2000; Zachos et al., 2001). Nevertheless, the success of ACEX has certainly opened the door for further scientific drilling in the Arctic Ocean. The ACEX results will frame the next round of questions to be answered from new drill holes to be taken by a series of drilling legs during the next decades.

\section{Workshop on "Arctic Ocean History: From Speculation to Reality"}

In order to discuss and plan the future of scientific drilling in the Arctic Ocean, an international workshop was held at the Alfred Wegener Institute in Bremerhaven, Germany, on 3-5 November 2008 (Coakley and Stein, 2008). The coauthors of this article convened that workshop. About ninety-five scientists from Europe, the U.S.A., Canada, Russia, Japan, and Korea as well as observers from oil companies participated in the workshop. All participants were invited to submit abstracts about their experiences, ideas and/or plans of Arctic Ocean research with special emphasis on drilling.

The major targets of the workshop were as follows: (1) to bring together an international group of Arctic scientists, 
young scientists, and ocean drilling scientists to learn and exchange ideas, experience, and enthusiasm about the Arctic Ocean; (2) to develop a scientific drilling strategy to investigate the tectonic and paleoceanographic history of the Arctic Ocean and its role in influencing the global climate system; (3) to summarize the technical needs, opportunities, and limitations of drilling in the Arctic; and (4) to define scientific and drilling targets for specific IODP-type campaigns in Arctic Ocean key areas to be finalized in the development of drilling proposals.

The first day of the workshop focused on presentations about the history of the Arctic Ocean, the legacy of high latitude ocean drilling, the existing site survey database, the possibilities of collaboration with industry, and the process of developing ocean-drilling legs through IODP. The next day and a half was spent in thematic and regional break-out groups discussing the particular questions to be addressed by drilling and the particular targets for Arctic scientific drilling. Within the working groups, key scientific questions, site surveys (available and needed), and strategies for reaching the overall goals were discussed, and-as one of the main results-core groups for further developing drilling proposals were formed.

Based on discussions at this meeting, a number of new proposals will be submitted to IODP in 2009/2010, a critical time both for the future of Arctic Ocean science and the future of scientific ocean drilling. As of October 2009, eight active Arctic-related proposals are listed in the IODP system (Table 1). Major themes (hypotheses to be tested by drilling) identified by the workshop participants may be summarized as follows:

\section{Paleoceanography:}

- Cyclicity between oxic, sub-oxic, and/or euxinic/anxoic conditions during the Cretaceous and Paleocene-Eocene

- Greenhouse vs. icehouse climate

- Polar amplification of greenhouse warming

- Hydrological cycle during greenhouse warming

- Onset of Eocene cooling

- Impact of Eocene-Oligocene transition in global pCO2 and sea level on the Arctic

- Onset and variability of sea-ice cover (seasonal vs. perennial ice cover)

- Circum-Arctic ice-sheet/ice-shelf history and dynamics

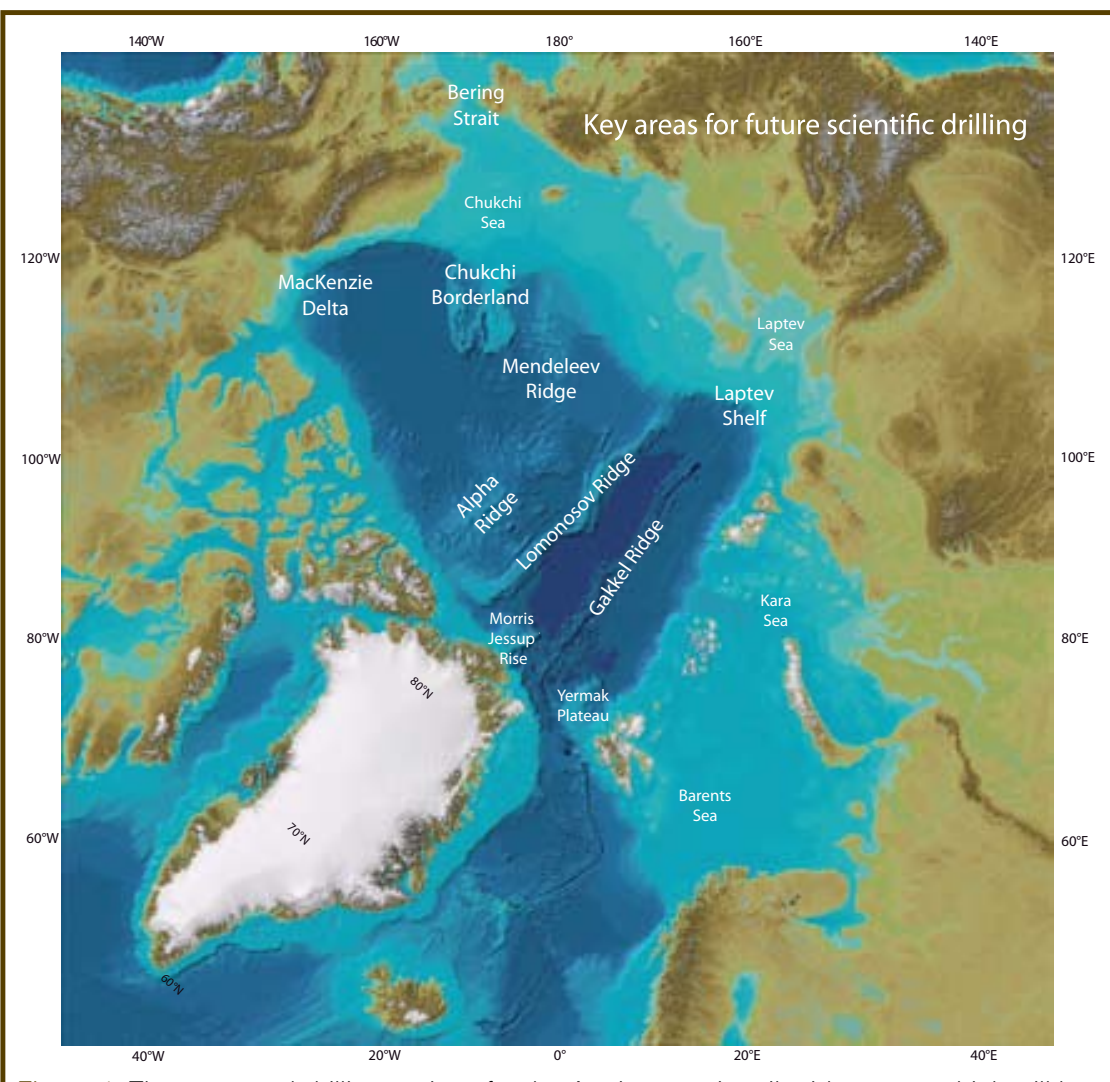

Figure 1. The proposed drilling regions for the Arctic are primarily ridge tops, which will have insed sections, making it possible to sample relatively long intervals without deep pened. There is also a desire for expanded, high resolution, sections, which can be recovered from the continental shelves. (Background map is from IBCAO, Jakobsson et al., 2008)

- Opening of Bering Strait/Fram Strait and its paleoceanographic consequences

- Causes of extended mid-Cenozoic unconformities

- Nature of the Arctic environment during periods of extreme events (warm/cold)

- Bipolar synchronous vs. asynchronous climate variability?

The varied sedimentary environments of the Arctic Ocean (Stein, 2008) enable two types of studies. Sampling on the tops of the ridges that segment the basin make it possible to collect records that span long intervals of geologic time. Focusing on the shelves and near-shelf areas make it possible to collect expanded, high-resolution records suitable for detailed paleo studies. At the workshop there was little interest in drilling into basinal sediments, given the expectation that these records are largely composed of turbidites and other mass-wasted sediments.

In order to study the long-term Mesozoic-Cenozoic evolution of the Arctic Ocean, we need to obtain undisturbed and complete sedimentary sequences to be drilled along depth transects across the major ocean ridge systems, i.e., the Lomonosov Ridge, the Alpha-Mendeleev Ridge, and the Chukchi Plateau/Northwind Ridge (Fig. 1). High-resolution records will enable detailed studies of climate variability on Milankovich and millennial to sub-millennial time scales. Appropriate sediments can be drilled along the circum-Arctic 
continental margins characterized by high sedimentation rates. Key areas, for example, are the Kara and Laptev seas and the Mackenzie shelf/slope characterized by large river discharge (Fig. 1). Key locations for studying the history of exchange of the Arctic Ocean with the world's oceans are the Fram Strait/Yermak Plateau and Chukchi Plateau areas (Fig. 1).

\section{Tectonics:}

- Mode of crustal extension in the Laptev Sea shelf

- Development of the Fram Strait gateway (mode of extension)

- Identification of plate boundaries (Chukchi Plateau)

- Age of magnetic anomalies (Canada Basin)

- Age and evolution of Alpha Ridge, Mendeleev Ridge, Makarov Basin, and Chukchi Plateau

- Correlation of onshore and offshore geology (Paleozoic sediments, Mesozoic magmatism)

- Understanding the 'Amerasia' side of Lomonosov Ridge

- Along-strike geologic variation of Lomonosov Ridge and consequences for Mesozoic evolution

\section{Petrology:}

- Gakkel Ridge (Fig. 1) mantle melting and geochemistry: western vs. eastern Gakkel Ridge (Global problem: how does continental lithospheric mantle contribute to melting of the asthenosphere? How does extent of melting change as spreading rate goes to zero?)

- Nature and origin of the Chukchi Borderland volcanism

- Origin of Alpha Mendeleev Ridge (hotspot track or segment of a large LIP?) Is the roughly synchronous volcanism recognized in America and Asia somehow related to a High Arctic Large Igneous Province?

\section{Gas Hydrates:}

The stability of gas hydrates and permafrost below the seafloor are intimately related to climate change (greenhouse gas reservoir). The dissociation of hydrates, which some believe is now underway, could release large quantities of methane to the atmosphere, acting as positive feedback driving global warming and further destabilizing sub-sea permafrost. These processes can destabilize the seafloor, enabling slope failures and thermo-karst as well as influencing biogeochemical processes. Gas hydrates may also be useful energy resources.

A pan-Arctic objective for scientific drilling would be to sample multiple locations that represent different aspects of gas hydrate $(\mathrm{GH})$ evolution and its relationship to climate and geologic history of the Arctic. These could include the MacKenzie shelf (most mature, representative of a deltaic end-member; Fig. 1), the Russian shelf (Laptev Sea, excellent location, wide shelf, but not as mature; Siberia excellent candidate for GH aspect; Fig 1), deep-water locations, particularly Mendeleev Ridge, where pockmarks and other seismic evidence support the presence and venting of subseafloor gases. Integrating the role of GH from these areas will be necessary to understand larger scale phenomena (e.g., carbon cycle).

\section{Site Surveys}

For the precise planning of future drilling campaigns (including site selection, evaluation of proposed drill sites for safety and environmental protection aspects, etc.), compre-

Table 1. Active Arctic-related IODP proposals (as of October, 2009). More details on these proposals including the list of co-proponents and involved institutions can be obtained from the IODP website (http://www.iodp.org/active-proposals).

\begin{tabular}{|c|c|c|c|c|c|c|}
\hline Number & Short Title & $\begin{array}{l}\text { Contract } \\
\text { Proponents }\end{array}$ & $\begin{array}{l}\text { University/ } \\
\text { Institute }\end{array}$ & Country & Platform* & E-mail \\
\hline 645-Full3 & $\begin{array}{l}\text { North Atlantic } \\
\text { Gateway }\end{array}$ & W. Jokat & $\begin{array}{l}\text { AWI } \\
\text { Bremerhaven }\end{array}$ & $\begin{array}{l}\text { ECORD/ } \\
\text { Germany }\end{array}$ & $\mathrm{MSP}+\mathrm{NR}$ & Wilfried.Jokat@awi.de \\
\hline 680-Full & $\begin{array}{l}\text { Bering Strait } \\
\text { Climate Change }\end{array}$ & S. J. Fowell & $\begin{array}{l}\text { University } \\
\text { of Alaska } \\
\text { Fairbanks }\end{array}$ & USA & MSP & ffsjf@uaf.edu \\
\hline 708-Pre & $\begin{array}{l}\text { Central Arctic } \\
\text { Paleoceanography }\end{array}$ & R. Stein & $\begin{array}{l}\text { AWI } \\
\text { Bremerhaven }\end{array}$ & $\begin{array}{l}\text { ECORD/ } \\
\text { Germany }\end{array}$ & MSP & Ruediger.Stein@awi.de \\
\hline 746-Pre & $\begin{array}{l}\text { Arctic Mesozoic } \\
\text { Climate }\end{array}$ & W. Jokat & $\begin{array}{l}\text { AWI } \\
\text { Bremerhaven }\end{array}$ & $\begin{array}{l}\text { ECORD/ } \\
\text { Germany }\end{array}$ & MSP & Wilfried.Jokat@awi.de \\
\hline 750-Pre & $\begin{array}{l}\text { Beringia Sea Level } \\
\text { History }\end{array}$ & L. Polyak & $\begin{array}{l}\text { Ohio State } \\
\text { University }\end{array}$ & USA & $\mathrm{MSP}+\mathrm{NR}$ & Polyak.1@osu.edu \\
\hline 753-Pre & $\begin{array}{l}\text { Beaufort Sea } \\
\text { Paleoceanography }\end{array}$ & M. O'Regan & $\begin{array}{l}\text { Stockholm } \\
\text { University }\end{array}$ & $\begin{array}{l}\text { ECORD/ } \\
\text { Sweden }\end{array}$ & NR & Matt.oregan@geo.su.se \\
\hline 755-Pre & $\begin{array}{l}\text { Arctic Slope } \\
\text { Stability }\end{array}$ & D. Winkelmann & GEOMAR & $\begin{array}{l}\text { ECORD/ } \\
\text { Germany }\end{array}$ & & dwinkelmann@ifm-geomar.de \\
\hline 756-Pre & $\begin{array}{l}\text { Morris Jesup } \\
\text { Rise: Drilling the } \\
\text { Arctic Ocean Exit } \\
\text { Gateway }\end{array}$ & M. Jakobsson & $\begin{array}{l}\text { Stockholm } \\
\text { University }\end{array}$ & $\begin{array}{l}\text { ECORD/ } \\
\text { Sweden }\end{array}$ & & Martin.jakobsson@geo.su.se \\
\hline
\end{tabular}


hensive site survey data are needed. The lack of good site survey data and age control for existing seismic reflection records is one of the biggest limitations on the development of Arctic Ocean scientific drilling (see the JEODI Report of Kristoffersen and Mikkelsen, 2004).

For some of the potential study areas, the site survey data base is already quite good. For example, from the Lomonosov Ridge, a large number of deep penetration reflection seismic profiles were acquired on icebreaker-based expeditions in 1991, 1996, 1998, and 2005 (Fütterer, 1992; Kristoffersen et al., 1997; Darby et al., 2005; Jokat, 2005 and further references therein). An intensive PARASOUND survey (in combination with coring) was carried out in 1995 and 1998 (Rachor, 1997; Jokat et al., 1999), and the first high-resolution chirp profiles were collected in 1996 (Jakobsson, 1999). In 1999, the SCICEX program collected high-resolution chirp sub-bottom profiler data, swath bathymetry and sidescan sonar backscatter data on Lomonosov Ridge from an American nuclear submarine (Edwards and Coakley, 2003), contributing significantly to the much improved bathymetric chart of the Arctic Ocean (Jakobsson, 2002; Jakobsson et al., 2008). During the 1995, 1996, and 1998 expeditions, a large number of sediment cores were taken by piston, gravity, and Kastenlot corers in the Lomonosov Ridge area (Backman et al., 1997; Rachor, 1997; Jokat et al., 1999; Stein et al., 2001). That means, in combination with the results from the ACEX drilling campaign (Backman et al., 2006, 2008), future drill areas/sites on Lomonosov Ridge can be identified more accurately. On the other hand, in other key areas for future drilling (e.g., the Alpha-Mendeleev Ridge), site survey expeditions still have to be carried out before a detailed planning and drill site selection can start.

\section{Outlook}

While sampling in the Arctic Ocean is called out as a priority in many of the sections of the IODP Science Plan, these priorities have yet to be realized in a sampling program of commensurate scope and urgency. Concerning the shortand long-term evolution of the Arctic Ocean and its importance for the understanding of the global climate history, most of the key questions mentioned above, as well as the key areas for scientific drilling in the Arctic Ocean, were already identified on several workshops during the last two decades and published in upcoming reports. Several, especially Thiede and the NAD Science Committee (1992), NAD (1997), Hovland (2001), Bowden et al. (2007), and Coakley and Stein (2009), have to be mentioned here. Over the years, however, scientific drilling in the ice-covered Arctic Ocean remained a dream. The ACEX drilling in 2004 (Backman, et al., 2006) was the first major step to transform this dream into reality. Now, further drilling campaigns are needed to follow up in the future. The construction of a new large icebreaker with deep-water drilling capability will certainly be the next milestone in Arctic Ocean research. Such a vessel would guarantee a commitment to Arctic deep drilling, and in combination with a continuous drilling program, could be a potential contribution to the IODP and succeeding programs, as already outlined in the APPG Report (Hovland, 2001). Plans for the development of Aurora Borealis, an icebreaker with deep-water drilling capability (Thiede and Egerton, 2004), are pushed forward over the last few years, and it seems possible that it will be completed and available for the international research community within the next decade. Operation of the Aurora Borealis would open a new dimension in multidisciplinary Arctic Ocean research.

\section{References}

Backman, J., and Moran, K., 2008. Introduction to special section on Cenozoic Paleoceanography of the Central Arctic Ocean. Paleoceanogr., 23:PA1S01, doi:10.1029/2007PA001516.

Backman, J., Jakobsson, M., Frank, M., Sangiorgi, F., Brinkhuis, H., Stickley, C., O'Regan, M., Løvlie, R., Pälike, H., Spofforth, D., Gattacecca, J., Moran, K., King, J., and Heil, C., 2008. Age model and core-seismic integration for the Cenozoic ACEX sediments from the Lomonosov Ridge. Paleoceanogr., 23:PA1S03, doi:10.1029/2007PA001476.

Backman, J., Jakobsson, M., Knies, J., Knudsen, J., Kristoffersen, Y., Lif, A., Musatov, E., and Stein, R., 1997. Geological coring and high-resolution chirp sonar profiling. In Grönlund, E. (Ed.), Cruise report, Polarforskningssekretaariatets arsbok 1995/96, Stockholm, 64-66.

Backman, J., Moran, K., Mayer, L.A., McInroy, D.B., and the Expedition 302 Scientists, 2006. Proc. IODP, 302, College Station, Texas (Integrated Ocean Drilling Program Management International, Inc.), doi:10.2204/iodp. proc.302.104.2006.

Bowden, S., Corell, R.W., Hassol, S.J., and Symon, C. (Eds.), 2007. Arctic Research: A global responsibility. ICARP-II (2nd International Conference on Arctic Research Planning), Copenhagen, Denmark, 10-12 November 2005, Canada (McCallum Printing Group Inc.), 36 pp. and CD-ROM.

Clark, D.L., Byers, C.W., and Pratt, L.M., 1986. Cretaceous black mud from the central Arctic Ocean. Paleoceanogr., 1:265-271, doi:10.1029/PA001i003p00265.

Clark, D.L., Whitman, R.R., Morgan, K.A., and Mackey, S.D., 1980. Stratigraphy and glacial marine sediments of the Amerasian Basin, central Arctic Ocean. Geol. Soc. Am. Spec. Pap., 181, $57 \mathrm{pp}$.

Coakley, B.J., and Stein, R., 2008. Workshop on "Arctic Ocean History: From Speculation to Reality”, Alfred Wegener Institute, Bremerhaven, Germany, 3-5 November 2008. Agenda and Abstract Book, 52 pp., http://www.essac.ecord.org/index. php? $\bmod =$ workshop\&page=workshop.

Coakley, B.J., and Stein, R., 2009. Arctic Ocean History: From Speculation to Reality. Alfred Wegener Institute, Bremerhaven, Germany, 3-5 November 2008. Workshop Report, ECORD Newsletter, 12:12 pp.

Darby, D.A., Jakobsson, M., and Polyak, L., 2005. Icebreaker expedition collects key Arctic seafloor and ice data. EOS, Trans. Am. Geophys. Union, 86(52):549-552, doi:10.1029/ 2005EO520001.

Edwards, M.H., and Coakley, B.J., 2003. SCICEX investigations of the Arctic Ocean system. Chemie der Erde, 63:281-392, 
doi:10.1078/0009-2819-00039.

Fütterer, D.K. (Ed.), 1992. ARCTIC '91: The Expedition ARK-VIII/3 of RV "Polarstern" in 1991. Rep. Polar Res., 107:1-267.

Hovland, M. (Ed.), 2001. The High-Arctic Drilling Challenge. Final Report of the Arctic's Role in Global Change Program Planning Group (APPG), Ocean Drilling Program, 38 pp.

Jakobsson, M., 1999. First high-resolution chirp sonar profiles for the central Arctic Ocean reveal erosion of Lomonosov Ridge sediments. Mar. Geol., 158:111-123, doi:10.1016/S00253227(98)00186-8.

Jakobsson, M., 2002. Hypsometry and volume of the Arctic Ocean and its constituent seas. Geochem., Geophys., Geosyst., 3:1-18, doi:10.1029/2001GC000302.

Jakobsson, M., Macnab, R., Mayer, L., Anderson, R., Edwards, M., Hatzky, J., Schenke, H.W., and Johnson, P., 2008. An improved bathymetric portrayal of the Arctic Ocean: Implications for ocean modeling and geological, geophysical and oceanographic analyses. Geophys. Res. Lett., 35:L07602, doi:10.1029/2008GL033520.

Jokat, W., 2005. The sedimentary structure of the Lomonosov Ridge between $88^{\circ} \mathrm{N}$ and $80^{\circ} \mathrm{N}$ : Consequences for tectonic and glacial processes. Geophys. J. Int., 163:698-726, doi:10.1111/ j.1365-246X.2005.02786.x.

Jokat, W., Stein, R., Rachor, E., and Schewe, I., 1999. Expedition gives fresh view of central Arctic geology. EOS, Trans. Am. Geophys. Union, 80(40):465, 472-473.

Kristoffersen, Y., and Mikkelsen, N. (Eds.), 2004. Scientific drilling in the Arctic Ocean and the site survey challenge: Tectonic, paleoceanographic and climatic evolution of the Polar Basin. Geological Survey of Greenland special publication, JEODI Workshop Report, Copenhagen, Denmark, 13-14 January 2003, http://www.ecord.org/about/j/wp5-wkshp.pdf.

Kristoffersen, Y., Buravtsev, V., Jokat, W., and Poselov, V., 1997. Seismic reflection surveys during Arctic Ocean-96. In Grönlund, E. (Ed.), Cruise report, Polarforskningssekretaariatets arsbok 1995/96, Stockholm, 75-77.

Lear, C.H., Elderfield, P.A., and Wilson, P.A., 2000. Cenozoic deepsea temperatures and global ice volumes from $\mathrm{Mg} / \mathrm{Ca}$ in benthic foraminiferal calcite. Science, 287:269-272, doi:10.1126/science.287.5451.269.

Miller, K.G., Fairbanks, R.G., and Mountain, G.S., 1987. Tertiary oxygen isotope synthesis, sea level history, and continental margin erosion. Paleoceanogr., 2:1-19, doi:10.1029/ PA002i001p00001.

Miller, K.G., Wright, J.D., and Fairbanks, R.G., 1991. Unlocking the ice house: Oligocene-Miocene oxygen isotopes, eustasy, and margin erosion. J. Geophys. Res., 96(B4):6829-6848, doi:10.1029/90JB02015.

Moran, K., Backman, J., Brinkhuis, H., Clemens, S.C., Cronin, T., Dickens, G.R., Eynaud, F., Gattacceca, J., Jakobsson, M., Jordan, R.W., Kaminski, M., King, J., Koc, N., Krylov, A., Martinez, N., Matthiessen, J., McInroy, D., Moore, T.C., Onodera, J., O’Regan, A.M., Pälike, H., Rea, B., Rio, D., Sakamoto, T., Smith, D.C., Stein, R., St. John, K., Suto, I., Suzuki, N., Takahashi, K., Watanabe, M., Yamamoto, M., Frank, M., Jokat, W., and Kristoffersen, Y., 2006. The Cenozoic palaeoenvironment of the Arctic Ocean. Nature, 441:601-605, doi:10.1038/nature04800.
NAD, 1997. Nansen Arctic Drilling Implementation Plan. Report of "Nansen Arctic Drilling Program Implementation Plan Workshop”, Arctic and Antarctic Research Institute, St. Petersburg, Russia, 14-15 October 1996, Joint Oceanographic Institutions, Washington, DC, 50 pp.

Pearson, P.N., and Palmer, M.R., 2000. Atmospheric carbon dioxide concentrations over the past 60 million years. Nature, 406:695-699, doi:10.1038/35021000.

Rachor, E. (Ed.), 1997. Scientific cruise report of the Arctic Expedition ARK-XI/1 of RV "Polarstern" in 1995. Rep. Polar Res., 226:1-157.

Stein, R., 2008. Arctic Ocean Sediments: Processes, Proxies, and Paleoenvironment. Developments in Marine Geology, 2, Amsterdam (Elsevier), $587 \mathrm{pp.}$

Stein, R., Boucsein, B., Fahl, K., Garcia de Oteyza, T., Knies, J., and Niessen, F., 2001. Accumulation of particulate organic carbon at the Eurasian continental margin during late Quaternary times: Controlling mechanisms and paleoenvironmental significance. Glob. Plan. Change, 31(1-4):87-104, doi:10.1016/S0921-8181(01)00114-X.

Thiede, J., and Egerton, P., 2004. AURORA BOREALIS: A Long-Term European Science Perspective for Deep Arctic Ocean Research 2006-2016. Strasbourg Cedex, France (European Science Foundation), $80 \mathrm{pp}$.

Thiede, J., and NAD Science Committee, 1992. The Arctic Ocean record: Key to global change (initial science plan). Polarforschung, 61(1):1-102.

Thiede, J., Clark, D.L., and Hermann, Y., 1990. Late Mesozoic and Cenozoic paleoceanography of the northern polar oceans. In Grantz, A., Johnson, L., and Sweeney, J.F. (Eds.), The Geology of North America, Vol. L, The Arctic Ocean Region, Boulder, Colo. (Geol. Soc. Am.), 427-458.

Thiede, J., Myhre, A.M., Firth, J.V., Johnson, G.L., and Ruddiman, W.F. (Eds.), 1996. Proc. ODP, Sci. Results, 151. College Station, Texas (Ocean Drilling Program), 685 pp.

Zachos, J., Pagani, M., Sloan, L., Thomas, E., and Billups, K., 2001. Trends, rhythms, and aberrations in global climate $65 \mathrm{Ma}$ to present. Science, 292:868-693, doi:10.1126/science. 1059412.

\section{Authors}

Bernard Coakley, Geophysical Institute, University of Alaska, Fairbanks, AL, U.S.A.; e-mail: Bernard.Coakley@ gi.alaska.edu.

Ruediger Stein, Alfred Wegener Institute for Polar and Marine Research, Bremerhaven, Germany; e-mail: Ruediger. Stein@awi.de.

\section{Related Web Link}

http://www.ngdc.noaa.gov/mgg/bathymetry/arctic/arctic. html 